\title{
PERANCANGAN SISTEM INFORMASI PERAWATAN MESIN MENGGUNAKAN PENDEKATAN ANALISIS BERORIENTASI OBJEK
}

\author{
Wilson Kosasih $^{1, a)}$, Iphov Kumala Sriwana ${ }^{2, b)}$ dan Winda Jeania Purnama ${ }^{3, c)}$ \\ ${ }^{1)}$ Staf Pengajar Program Studi Teknik Industri Universitas Tarumanagara \\ ${ }^{2)}$ Staf Pengajar Program Studi Teknik Industri Universitas Esa Unggul \\ 3) Alumni Program Studi Teknik Industri Universitas Tarumanagara \\ e-mail: a)wilsonk@ft.untar.ac.id ; b)iphovkumala@gmail.com ; ${ }^{\mathrm{c})}$ winda.jeania@gmail.com
}

\begin{abstract}
ABSTRAK
Makalah ini membahas sebuah rancangan sistem informasi yang berkaitan dengan manajemen perawatan mesin sehingga dapat menjalankan perawatan terencana secara optimal. Rancangan sistem informasi ini dikembangkan menggunakan pendekatan analisis berorientasi objek dengan unified modelling Language. Hasil rancangan ini akan mempermudah pelaksanaan manajemen perawatan dan manajemen berbasis data, seperti dapat mengetahui berbagai informasi mengenai personil perawatan, mesin, suku cadangnya, dan stok dari komponen, serta membuat form work order, permintaan komponen, pengontrolan harian, dan jadwal perawatan.
\end{abstract}

Kata Kunci: manajemen perawatan, sistem informasi, analisis berorientasi objek.

\begin{abstract}
This paper discusses a design of information system related to management of machine maintenance so that it could carry out planned maintenance optimally. This IS design was developed using object oriented analysis approach with unified modeling language. This result of design would help maintenance management implementation and data-based management such as finding out the various of informations concerning with maintenance personnel, machinery, its components, and stock of a component, as well as to create work order form, component request, daily control, and maintenance schedule.
\end{abstract}

Keywords: maintenance management, information system, object oriented analysis

\section{PENDAHULUAN}

Manajemen perawatan mesin merupakan aspek penting yang menentukan keberhasilan dan keberlanjutan suatu industri manufaktur. Perkembangan teknologi informasi memberikan peluang baru bagi peningkatan kinerja manajemen perawatan, salah satu penerapannya adalah pengelolaan berbagai jenis data seperti kerusakan mesin, perbaikan mesin dan sebagainya menggunakan sistem informasi yang dapat meningkatkan efektivitas dan efisiensi aktivitas manajemen perawatan mesin [1].

PT X merupakan perusahaan yang bergerak dalam bidang produksi sol sepatu. Divisi maintenance belum menerapkan manajemen perawatan dengan baik, hal ini dapat dilihat dari tidak adanya dokumentasi data kerusakan dan perawatan mesin, sehingga perusahaan tidak dapat menentukan jadwal perawatan secara optimal dan tidak dapat menentukan biaya yang ditimbulkan oleh aktivitas perawatan secara langsung. Oleh karena itu, perusahaan membutuhkan sebuah sistem informasi yang mampu mendukung tersedianya data-data yang dibutuhkan dan mampu mempermudah proses pencatatan dan penyimpanan data, dimana data-data tersebut dapat dikelola menjadi informasi yang berguna sehingga dapat dijadikan sebagai pertimbangan untuk mengambil kebijakan perawatan. Pada perancangan ini, sistem informasi yang dikembangkan menggunakan pendekatan Object Oriented Analysis (OOA) dengan Unified Modelling Language (UML). Melalui pendekatan terhadap objek dari sistem nyata, sudut pandang pembuatan program akan diselaraskan dengan sistem nyata, sehingga pemodelannya ke dalam bahasa program menjadi realistis. 


\section{TINJAUAN PUSTAKA}

\section{Sistem Informasi Manajemen}

Sistem informasi pada level manajemen berfungsi untuk membantu perencanaan, pengendalian, dan pengembalian keputusan dengan menyediakan resume rutin dan laporanlaporan tertentu. Sistem infomasi manajemen mengambil data mentah dan mengubahnya menjadi kumpulan data yang lebih berarti serta dibutuhkan manajer untuk menjalankan tanggung jawabnya. Untuk mengembangkan suatu sistem informasi manajemen, diperlukan pemahaman yang baik tentang informasi apa saja yang dibutuhkan manajer dan bagaimana mereka menggunakan informasi tersebut [2].

\section{Object-Oriented Analysis}

Object-oriented analysis (OOA) atau analisis berorientasi objek menggambarkan sistem informasi dengan mengidentifikasi halhal yang disebut objek. Sebuah objek mewakili orang, tempat, kejadian, atau transaksi. Misalnya, ketika seorang pasien membuat janji untuk menemui dokter, pasien adalah objek, dokter adalah objek, dan penetapan janji adalah sebuah objek. Analisis berorientasi objek adalah pendekatan populer yang melihat sebuah sistem dari pandangan objek itu sendiri sesuai fungsi dan interaksi mereka [3]. Ada beberapa keuntungan pemrograman dengan berorientasi objek, yaitu [4]:

a. Realistic modeling: melalui pendekatan terhadap objek yang ditiru dari dunia nyata, sudut pandang pembuatan program akan selaras dengan realitas dunia nyata, sehingga pemodelan sistem dunia nyata ke program menjadi realistis

b. Fleksibilitas untuk berubah: program dapat mengikuti perubahan sistem dengan mudah karena hanya mengubah objek-objek sistem yang berubah, tanpa membuang kode program objek lain yang tidak berbuah.

c. Reusability: kode objek-objek suatu program dapat digunakan pada projek program lain yang kebetulan mempunyai kondisi objek yang sama, sehingga tidak perlu menulis ulang keseluruhan kode projek program.

\section{Unified Modelling Language (UML)}

Dalam mengembangkan sistem berorientasi objek, dapat digunakan unified modeling language (UML) yaitu, teknik populer untuk mendokumentasikan dan memodelkan sistem. UML menggunakan seperangkat simbol untuk mewakili secara grafis berbagai komponen dan hubungan dalam suatu sistem. Berikut beberapa contoh UML yang sering digunakan [1]:

a. Use Case Diagram

Use case diagram adalah diagram visual yang menggambarkan interaksi antara pengguna dengan sistem informasi. Simbol UML untuk use case adalah oval dengan label yang menjelaskan tindakan atau peristiwa. Aktor digambarkan dengan gambar orang dengan label yang menjelaskan peran aktor. Garis dari aktor ke use case disebut hubungan, karena menghubungkan aktor tertentu dengan use case.

b. Sequence Diagram

Sequence diagram menunjukkan interaksi antar beberapa objek dalam satuan waktu. Interaksi berlangsung dari atas ke bawah sepanjang garis waktu vertikal, sementara panah horizontal mewakili pesan dari satu objek ke objek lainnya. Sequence diagram secara grafis mendokumentasikan use case dengan menampilkan kelas, pesan, dan waktu pesan.

c. Class Diagram

Class diagram menunjukkan sekumpulan kelas objek dan hubungan yang terlibat dalam sebuah use case. Simbol UML untuk kelas adalah persegi panjang, dengan nama kelas di atas, diikuti oleh atribut dan metode kelas. Garis menunjukkan hubungan antara kelas dan memiliki label yang mengidentifikasi tindakan yang berhubungan dengan dua kelas. Diagram kelas juga mencakup konsep yang disebut kardinalitas, yang menggambarkan bagaimana caranya satu kelas berhubungan dengan kelas lain.

\section{METODOLOGI PERANCANGAN}

Perancangan ini dilakukan di divisi maintenance PT X. Tahap pertama adalah 
melakukan survey sistem perawatan yang diterapkan oleh perusahaan melalui wawancara dan diskusi dengan pihak terkait, dengan tujuan mencari kebutuhan pengguna sistem. Melakukan pengumpulan data yang dibutuhkan bagi pengembangan sistem seperti data mesin, komponen, stok komponen, karyawan maintenance, rekapitulasi data kerusakan mesin serta data-data lainnya yang diperlukan. Melakukan analisis sistem perawatan usulan dengan mempelajari kekurangan yang ada pada sistem sehingga dapat diketahui gambaran sistem informasi yang akan dirancang. Tahap selanjutnya adalah memodelkan sistem informasi menggunakan pendekatan analisis berorientasi objek. Penggambaran model dilakukan menggunakan diagram UML yaitu use case diagram, class diagram, dan sequence diagram. Perancangan use case diagram bertujuan untuk mengetahui fungsi apa saja yang ada di dalam sebuah sistem dan siapa saja yang berhak menggunakan fungsi-fungsi tersebut. Perancangan sequence diagram untuk menggambarkan interaksi antar objek saat menjalankan suatu use case. Perancangan class diagram untuk menggambarkan struktur, deskripsi dan hubungan dari semua objek yang terlibat di dalam sistem. Tahap terakhir adalah merancang sistem informasi berdasarkan hasil pemodelan sistem menggunakan bahasa pemrograman C\# dan database SQL.

\section{HASIL DAN PEMBAHASAN}

Sistem perawatan mesin yang ada di perusahaan saat ini masih kurang baik dan bersifat tradisional. Hal ini dapat dilihat dengan tidak adanya jadwal terencana untuk melakukan perawatan mesin. Perawatan yang dilakukan saat ini bersifat Run To Failure yaitu perawatan yang dilakukan setelah mesin mengalami kerusakan. Perawatan rutin yang dilakukan dalam jangka waktu tertentu hanya berdasarkan pengalaman para teknisi. Data kerusakan dan perawatan mesin juga tidak didokumentasikan dengan baik, pencatatan data yang dilakukan hanya dalam bentuk inventaris komponen di gudang dan ditulis secara manual dalam sebuah buku. Selain itu, setiap akhir bulan bagian gudang akan menghitung stok komponen yang tersisa secara manual dan melaporkannya kepada kepala teknisi untuk penambahan stok jika diperlukan.

Sistem informasi yang dirancang dapat mendukung tersedianya data-data yang dibutuhkan dan mampu mempermudah proses pencatatan dan penyimpanan data, dimana datadata tersebut dapat dikelola menjadi informasi yang berguna sehingga dapat dijadikan sebagai pertimbangan untuk mengambil kebijakan perawatan. Sistem informasi yang akan dibangun ini dapat melakukan beberapa fungsi antara lain:

a. Dapat mengetahui informasi mengenai data karyawan bagian maintenance, mesin beserta komponennya.

b. Dapat mengetahui secara lengkap data gangguan/kerusakan yang terjadi pada mesin berdasarkan informasi yang terdapat pada Work Order seperti kerusakan apa yang terjadi, penyebab terjadinya kerusakan, tindakan yang dilakukan, teknisi yang bertugas, tanggal/jam mulai dan selesai kerusakan, estimasi biaya yang dikeluarkan, dll.

c. Dapat mencatat data hasil pengontrolan jika ditemukan adanya keanehan atau indikasi kerusakan dimana mesin tidak bekerja seperti biasa yang tidak perlu diperbaiki saat itu. Hasil dari pengontrolan ini nantinya akan dianalisa kepala teknisi, apakah keanehan atau indikasi tersebut harus segera diperbaiki ataukah masih dapat digunakan, jika harus diperbaiki, maka kepala teknisi akan membuat Work Order untuk dilakukan kegiatan perbaikan

d. Dapat membuat jadwal perawatan berdasarkan interval waktu yang telah ditetapkan sehingga informasi tersebut dapat menjadi pengingat kapan waktu untuk melakukan perawatan.

e. Dapat mengetahui informasi stok komponen yang tersedia di gudang, dimana pada saat penerimaan stok, bagian gudang akan melakukan penginputan secara manual ke komputer, secara otomatis data stok bertambah. Pada saat pengambilan stok, secara otomatis sistem akan mengurangi jumlah stok yang ada. Proses pengambilan stok ini terjadi pada saat pengisian form permintaan komponen. 


\section{Perancangan Use Case Diagram}

Use case diagram menggambarkan aktor dan hubungan dengan fungsinya masingmasing. Dalam sistem informasi perawatan mesin PT Trimukti Wirapratama terdapat 3 aktor yaitu kepala teknisi, shift leader, dan bagian gudang. Use case diagram dapat dilihat pada Gambar 1.

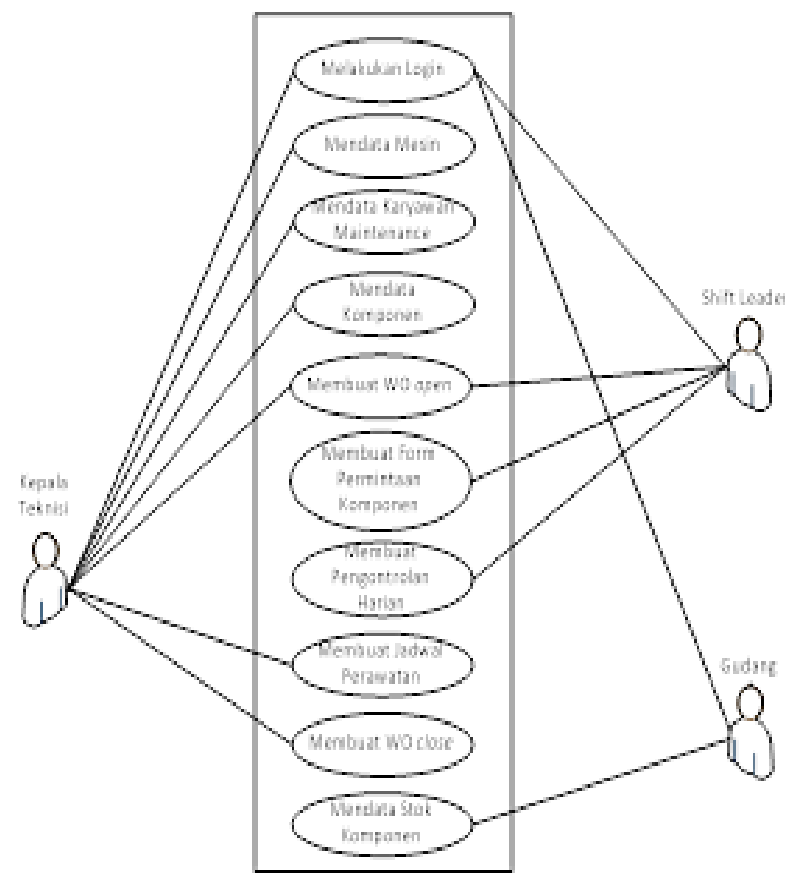

Gambar 1. Use Case Diagram

\section{Perancangan Sequence Diagram}

Sequence diagram adalah diagram yang menggambarkan interaksi antar objek saat menjalankan suatu use case. Diagram ini menunjukkan bahwa eksekusi dari sebuah operasi yang dimiliki sebuah objek akan melibatkan pemanggilan operasi pada objek lainnya, atau dengan kata lain, sequence diagram menunjukkan relasi antara objek-objek dan operasinya. Contoh sequence diagram login dan mendata karyawan/personil maintenance, membuat Work Order yang dapat dilihat pada Gambar 2, Gambar 3, dan Gambar 4.

\section{Perancangan Class Diagram}

Class Diagram digambarkan untuk menunjukkan hubungan-hubungan antar class dan atribut maupun operasi yang dimiliki masing-masing class. Class diagram dapat dilihat pada Gambar 5.

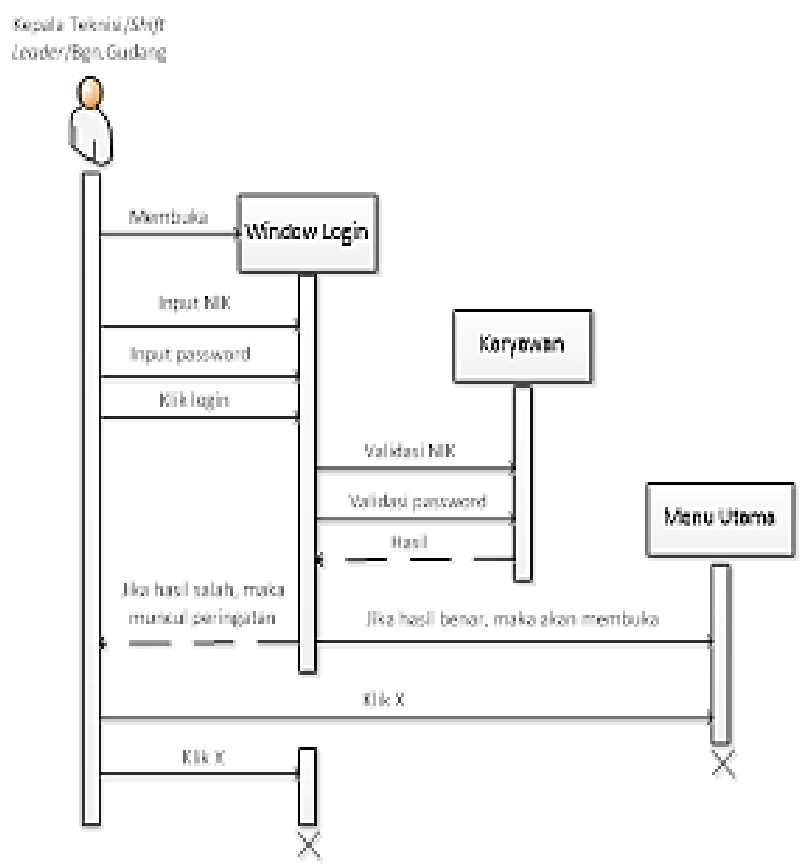

Gambar 2. Sequence Diagram Login

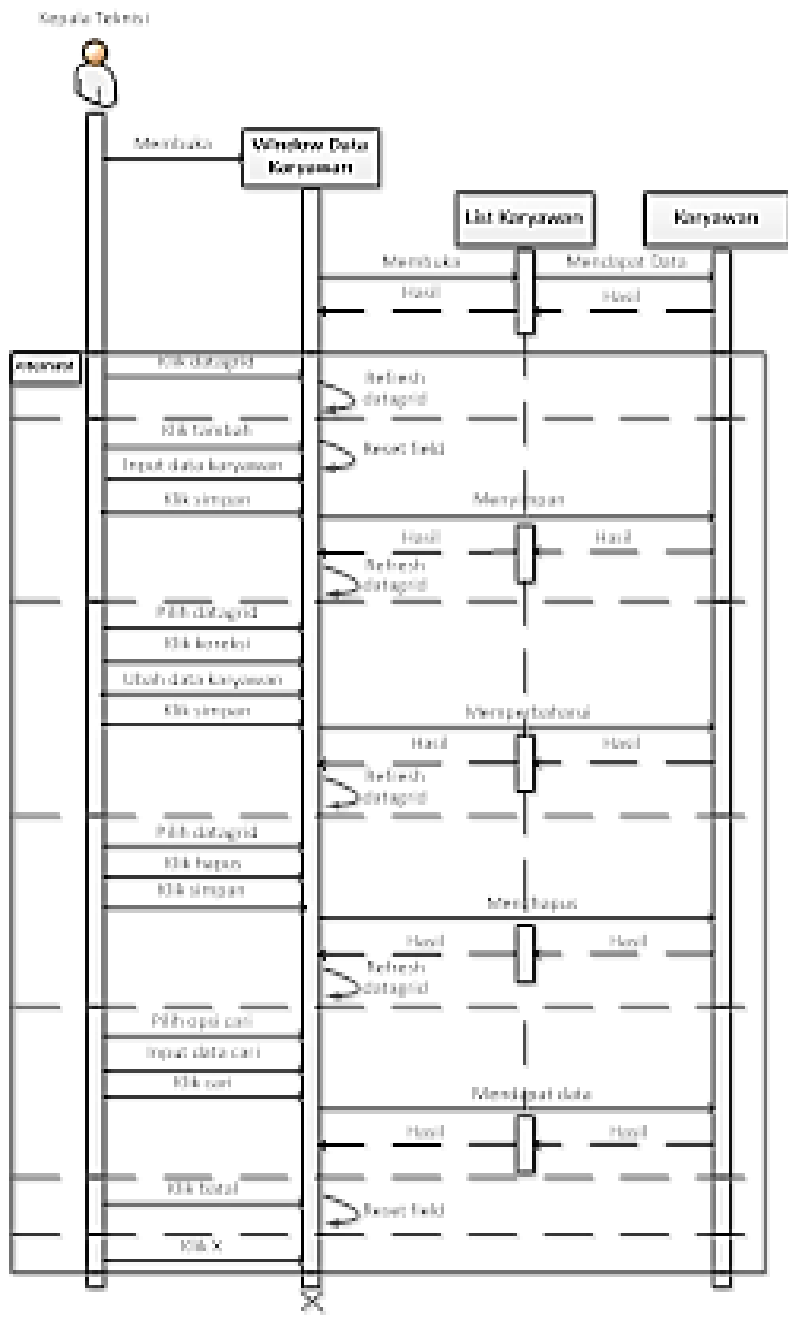

Gambar 3. Sequence Diagram Mendata Personil Maintenance 


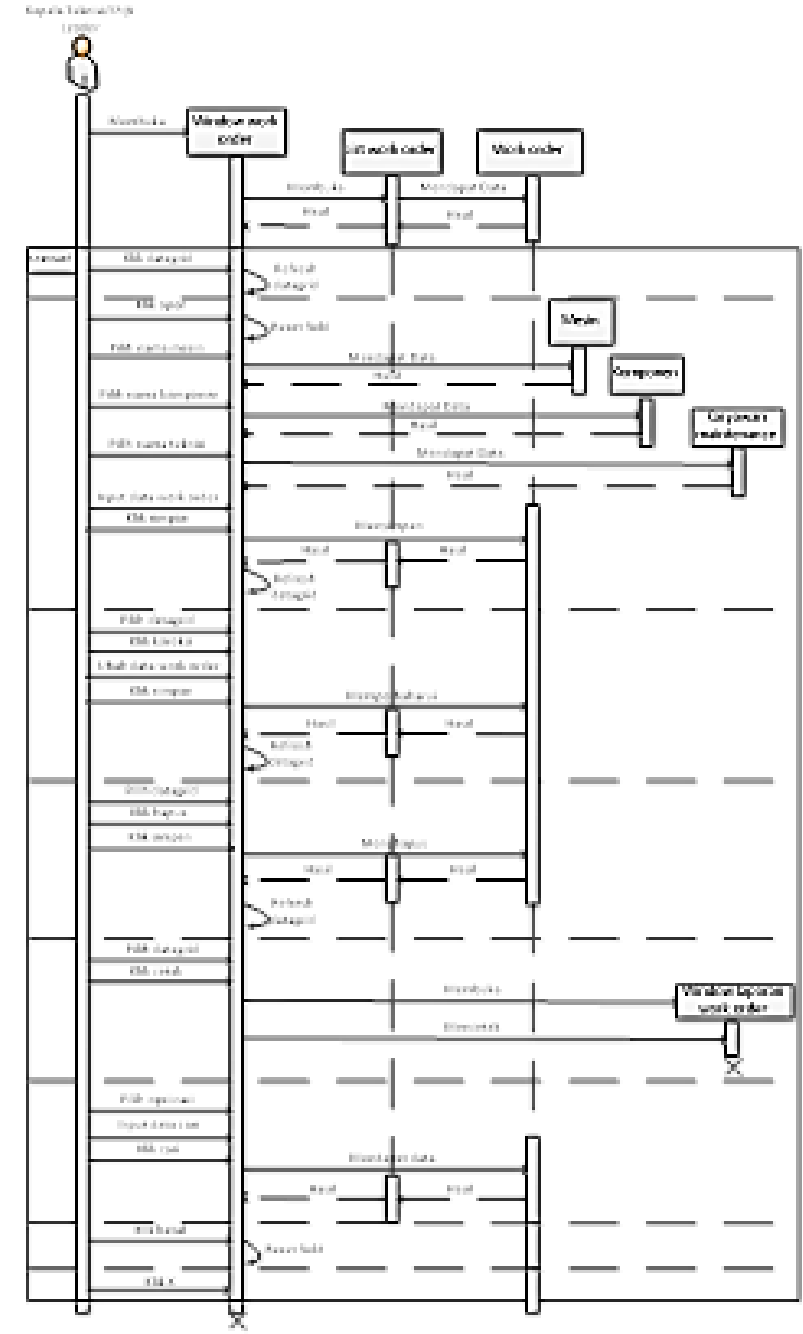

Gambar 4. Sequence Diagram Membuat Work Order

\section{Hasil Rancangan Aplikasi}

Hasil rancangan dari program yang telah dibuat, dibangun dengan bahasa pemrograman C\# dan database SQL.

\section{a. Login}

Tampilan login dapat dilihat pada Gambar 6. User diwajibkan untuk melakukan login terlebih dahulu dengan memasukkan NIK (Nomor Induk Karyawan) dan password. Sistem akan melakukan validasi apakah NIK dan password yang dimasukkan adalah benar, jika iya maka user dapat mengakses menu utama, tetapi jika salah maka akan muncul kotak peringatan.

b. Menu Utama

Menu utama disajikan dalam bentuk pull down menu, dimana setiap menu bar terdapat sub menu yang masing-masing memiliki fungsi berbeda untuk membantu aktivitas perawatan, yaitu: Menu File (logout dan keluar), Menu Data (data karyawan, data mesin, data komponen, dan data stok komponen), Menu Form (work order, permintaan komponen, dan pengontrolan harian), dan Menu Jadwal Perawatan yang dapat dilihat pada Gambar 7.

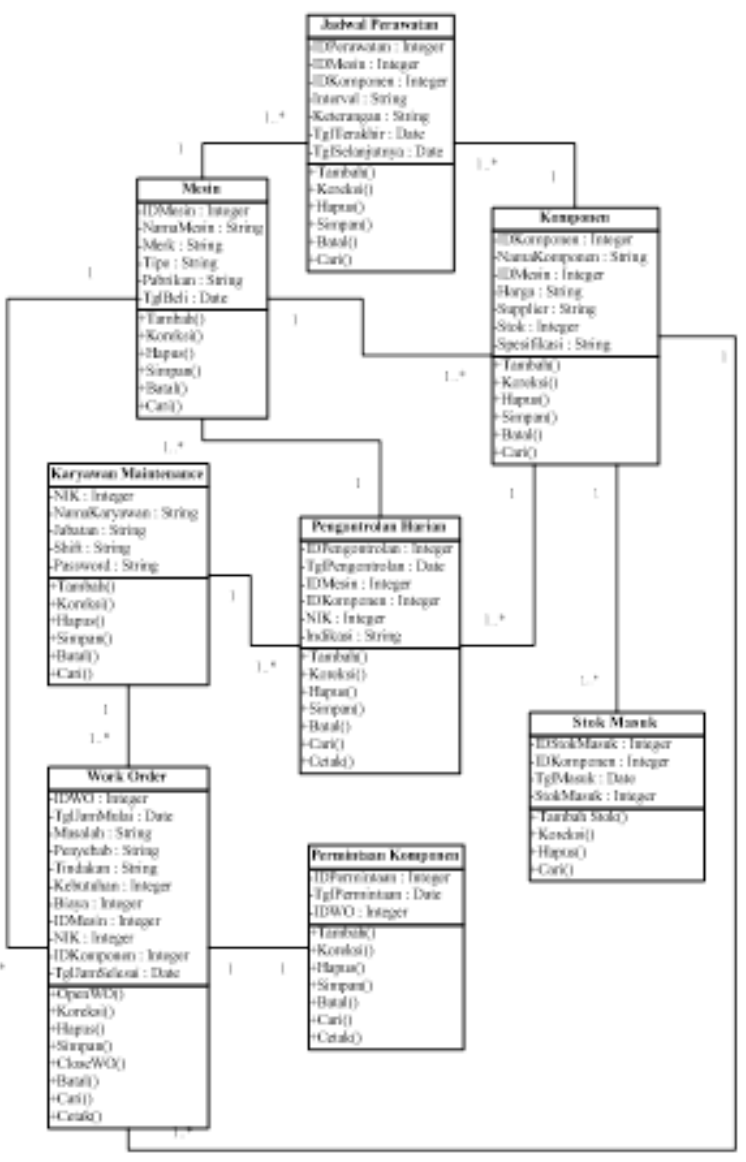

Gambar 5. Class Diagram

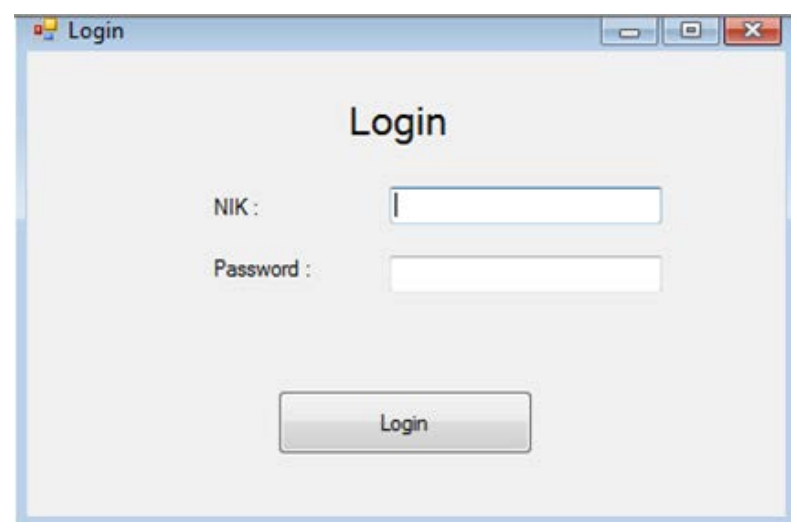

Gambar 6. Tampilan Login 


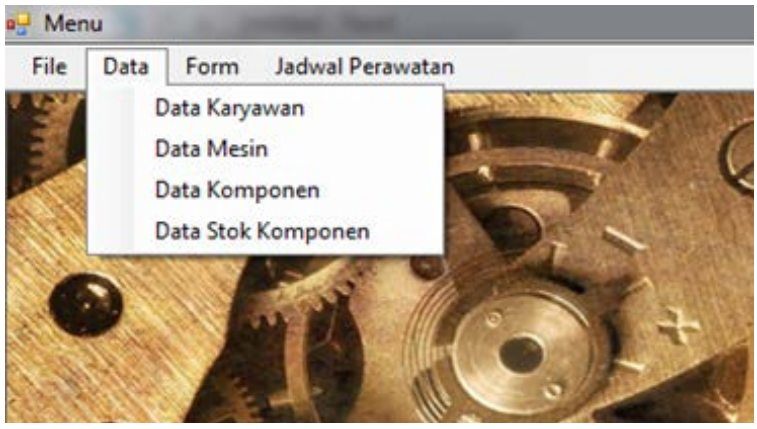

Gambar 7. Tampilan Menu Utama

c. Data Karyawan Maintenance

Tampilan data karyawan maintenance ditunjukkan pada Gambar 8, berguna untuk mengolah data karyawan/personil maintenance.

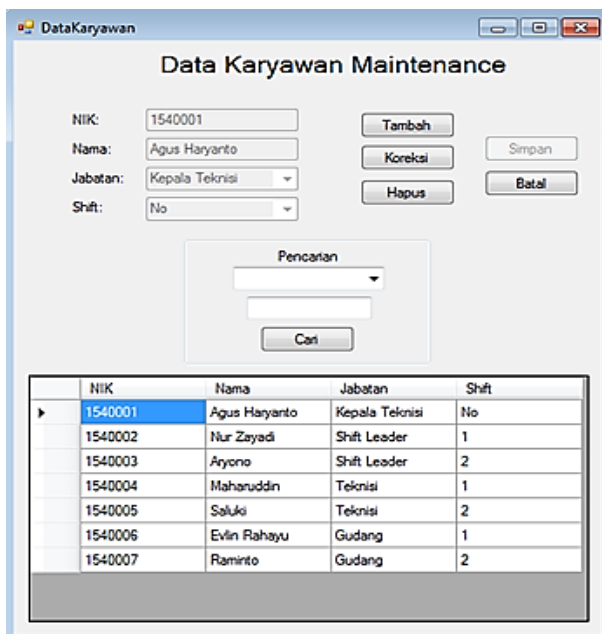

Gambar 8. Tampilan Data Personil

\section{Maintenance}

d. Data Mesin

Tampilan data mesin ditunjukkan pada Gambar 9, berguna untuk mengolah data mesin.

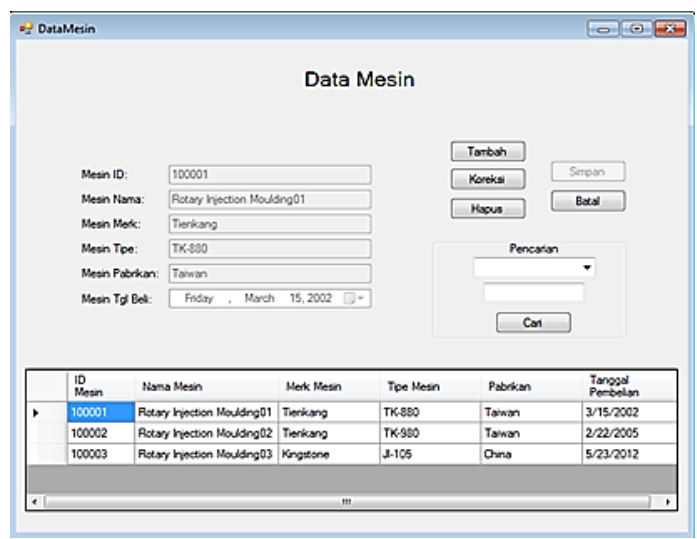

Gambar 9. Tampilan Data Mesin e. Data Komponen

Tampilan data komponen ditunjukkan pada Gambar 10, berguna untuk mengolah data komponen pada tiap mesin.

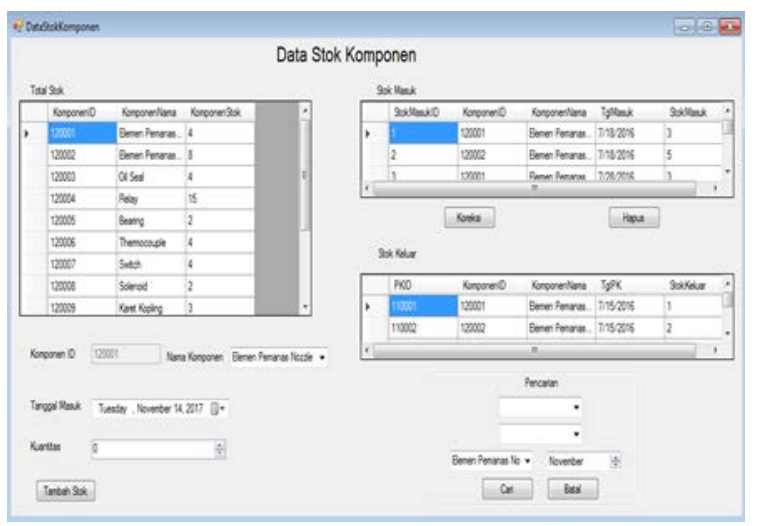

Gambar 10. Tampilan Data Komponen

f. Data Stok Komponen

Tampilan data stok komponen ditunjukkan pada Gambar 11, berguna untuk mengolah data stok komponen, apabila terjadi penambahan stok, maka jumlah stok akan otomatis bertambah sesuai kuantitas stok masuk, begitu juga sebaliknya jumlah stok akan berkurang apabila terjadi transaksi stok keluar akibat adanya permintaan komponen yang dibuat.

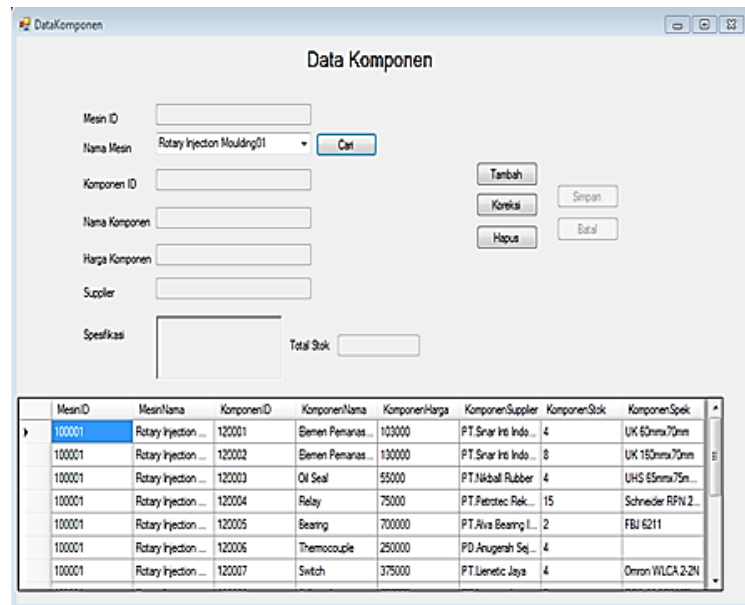

Gambar 11. Tampilan Data Stok Komponen

g. Formulir Pesanan Kerja

Tampilan form dan laporan cetak pesanan kerja (work order) ditunjukkan pada Gambar 12 dan Gambar 13, berguna untuk 
membuat perintah kerja yang dikeluarkan oleh kepala teknisi dan diberikan kepada shift leader/teknisi untuk segera melakukan kegiatan perawatan. Formulir ini merupakan poin penting karena data pada WO dapat dijadikan informasi berguna untuk mengambil kebijakan perawatan.

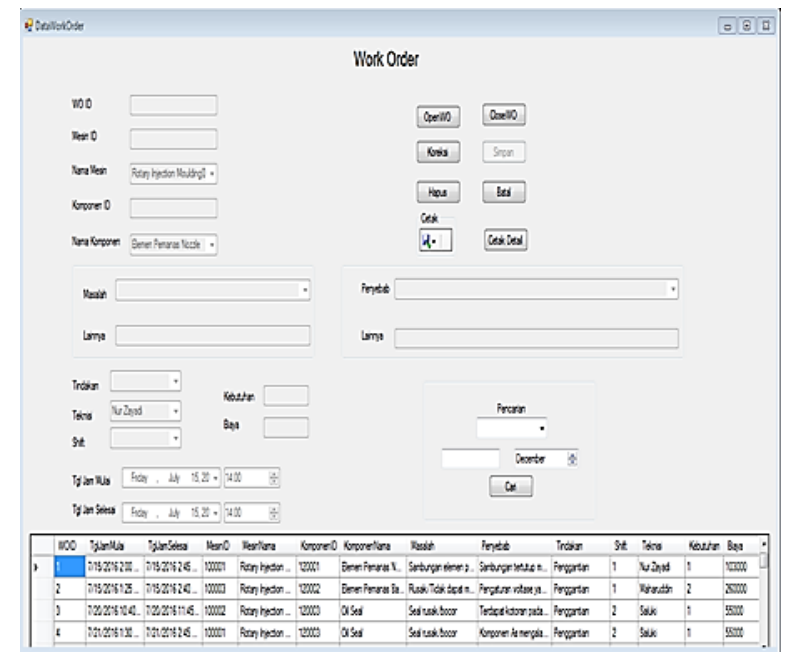

Gambar 12. Tampilan Formulir Pesanan Kerja

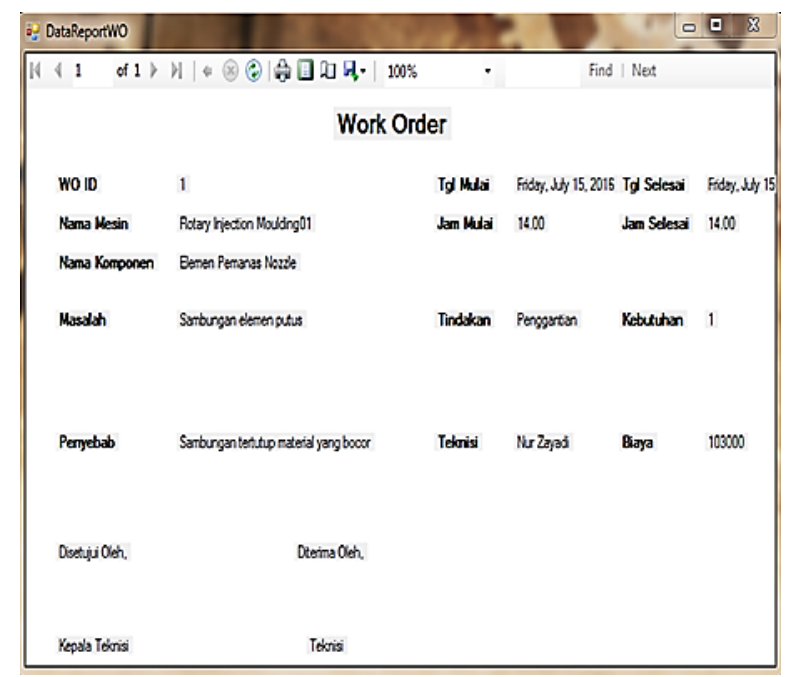

Gambar 13. Tampilan Laporan Cetak Pesanan Kerja

h. Form Permintaan Komponen

Tampilan form dan laporan permintaan komponen ditunjukkan pada Gambar 14 dan Gambar 15, berguna untuk membuat permintaan komponen yang dibutuhkan ke bagian gudang.

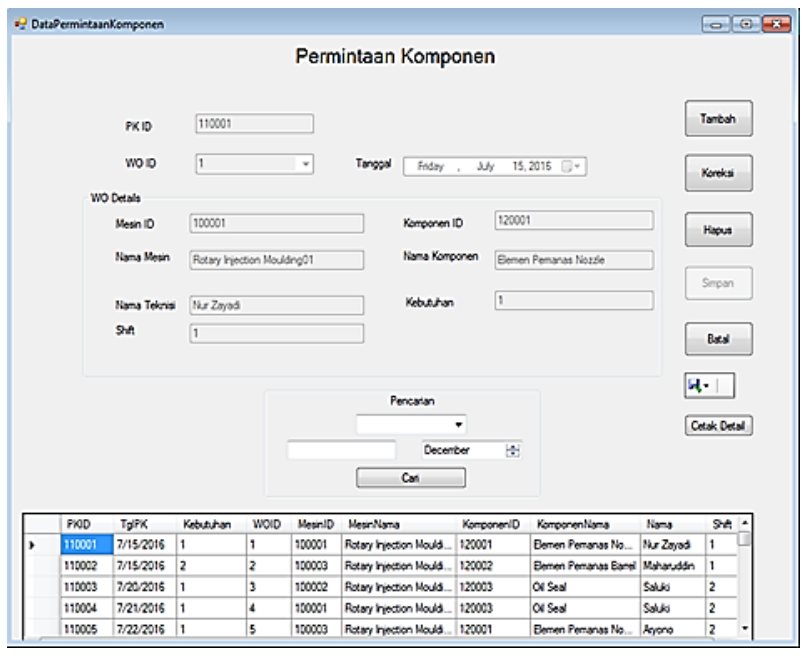

Gambar 14. Tampilan Formulir Permintaan Komponen

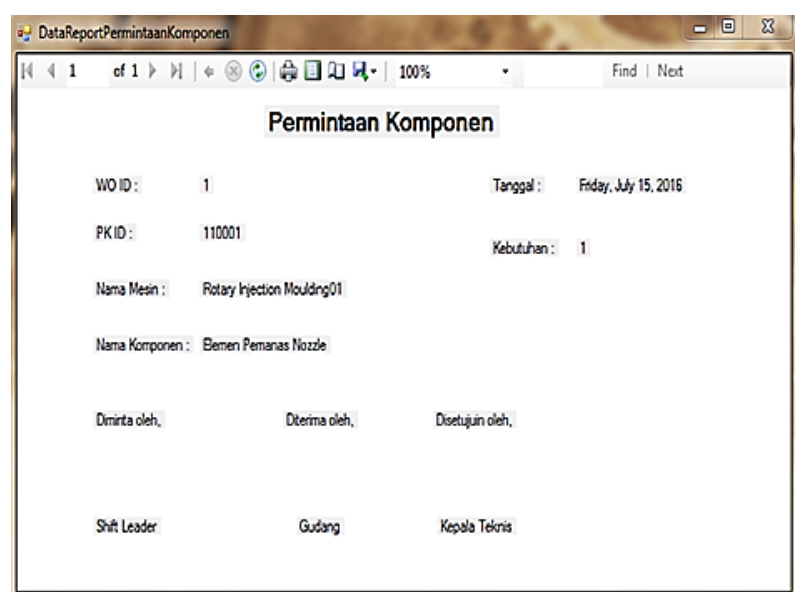

Gambar 15. Tampilan Laporan Permintaan Komponen

i. Formulir Pengontrolan Harian

Tampilan form pengontrolan harian ditunjukkan pada Gambar 16, berguna untuk mendata hasil pengontrolan mesin yang dilakukan setiap hari oleh shift leader/teknisi.

j. Jadwal Perawatan

Tampilan jadwal perawatan ditunjukkan pada Gambar 17, berguna untuk membuat jadwal perawatan setiap komponen yang ada pada mesin sebagai suatu pedoman dalam merencanakan suatu perawatan secara berkala. 


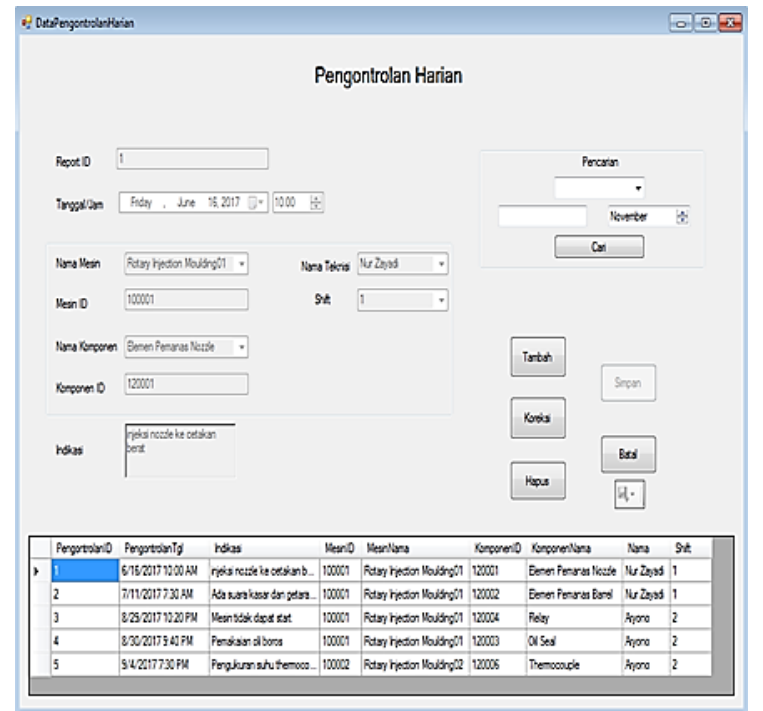

Gambar 16. Tampilan Formulir Pengontrolan Harian

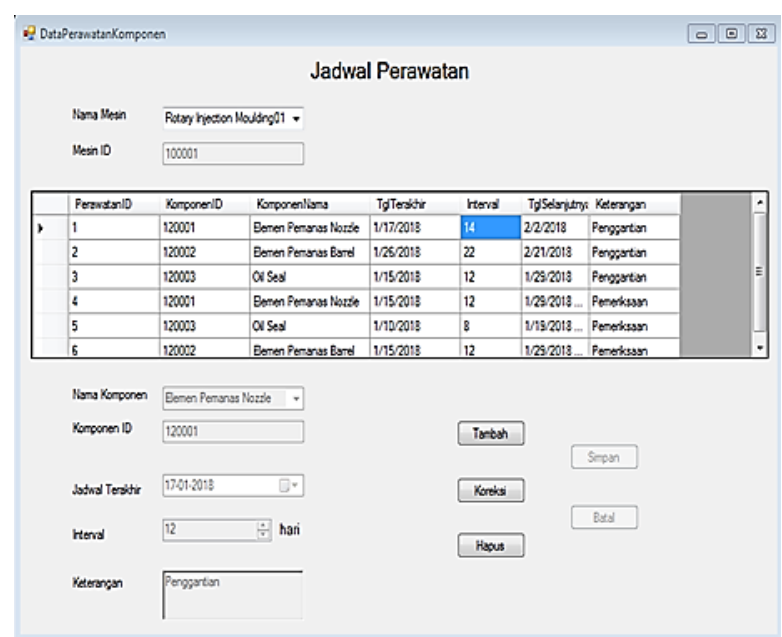

Gambar 17. Tampilan Jadwal Perawatan

\section{KESIMPULAN}

Hasil perancangan sistem informasi perawatan mesin dapat mempermudah pengelolaan dan pemanfaatan data perawatan mesin seperti data karyawan bagian maintenance, data mesin beserta komponennya, data stok komponen di gudang, data gangguan/kerusakan yang terjadi pada mesin berdasarkan informasi pada Work Order seperti kerusakan apa yang terjadi, penyebab terjadinya kerusakan, tindakan yang dilakukan, teknisi yang bertugas, tanggal/jam mulai dan selesai kerusakan, estimasi biaya yang dikeluarkan, dll, data permintaan komponen setiap ada tindakan penggantian pada Work Order, data indikasi kerusakan berdasarkan informasi pada pengontrolan harian, dan jadwal perawatan berdasarkan interval waktu yang telah ditetapkan. Kondisi ini lebih baik dari kondisi sebelumnya dimana tidak terdapat rekapitulasi data kerusakan dan perawatan mesin yang jelas sehingga menyulitkan kepala teknisi dalam mengambil keputusan yang berkaitan dengan perawatan mesin

\section{DAFTAR PUSTAKA}

[1] Yuliandra, B. \& Jaeba, K. A. Perancangan Sistem Informasi Perawatan Mesin Pada PT XYZ. Padang: Universitas Andalas, 2017.

[2] Muslihudin, M., dan Oktafianto. Analisis dan Perancangan Sistem Informasi Menggunakan Model Terstruktur dan UML. Yogyakarta: CV Andi Offset, 2016.

[3] Shelly, G.B \& J. H. Rosenblatt. Systems Analysis and Design, Ninth Edition. Boston: Course Technology, 2012.

[4] Wardana. Membuat Aplikasi Berbasis Pendekatan Sistem dengan Visual Basic Net 2008. Jakarta: PT Elex Media Komputindo, 2008. 